J. Product. \& Dev., 12(1): 173 - 199 (2007)

\title{
RESPONSE OF SUMMER ANNUAL FLOWERING PLANTS TO CHEMICAL, ORGANIC AND BIO-FERTILIZATION TREATMENTS \\ II- AFRICAN MARIGOLD (Tagetes erecta L.) PLANTS
}

\author{
E.I. El-Maadawy \\ Ornamental Horticulture Department, Faculty of Agriculture, Cairo \\ University, Egypt.
}

\section{ABSTRACT}

This study was carried out at the Experimental Nursery of the Ornamental Horticulture Department, Faculty of Agriculture, Cairo University, Giza, during the two successive seasons of 2000 and 2001, with the aim of investigating the effect of chemical, organic and biofertilization treatments on the growth, chemical composition and oil production of African marigold (Tagetes erecta L.) plants. In addition to the control, the fertilization treatments included: (1) $N$ fertilization at the rates of 6 or $12 \mathrm{~g}$ ammonium sulphate /pot ( $N_{1}$ and $N_{2}$, respectively), (2) Bio-fertilization (Bio), (3) Bio + half the previous $N$ fertilization rates $\left(1 / 2 N_{1}\right.$ or $\left.N_{1}\right)$, (4) Cattle manure (CM) at the rate of $710 \mathrm{~cm}^{3} / p o t$ (equivalent to $40 \mathrm{~m}^{3} / \mathrm{feddan}$ ), or (5) Bio $+1 / 2 C M$ (i.e., $C M$ at 355 $\mathrm{cm}^{3} /$ pot, equivalent to $20 \mathrm{~m}^{3} /$ feddan). All plants (including the control) received chemical $P K$ fertilization ( $P$ at $6 \mathrm{~g}$ calcium superphosphate, and $K$ at $3 \mathrm{~g}$ potassium sulphate /25-cm pot). The bio-fertilizer was applied to the soil as a liquid inoculum containing Azospirillum brasilense, Klebsiella pneumonia and Pseudomonas putida.

In general, all the tested fertilization treatments had a favourable effect on vegetative growth, flowering, chemical composition and oil production. In most cases, fertilization with CM (especially when added without bio-fertilization) gave the highest values for the different vegetative growth characteristics (plant height, number of branches, fresh and dry weights of leaves, stems and roots). Also, CM (with or without biofertilization) gave the best results for number of flowers/plant, as well as fresh and dry weights of flowers (in most cases). Fertilization treatments also increased the leaf contents of chlorophylls " $a$ ", " $b$ ", total chlorophylls, carotenoids and xanthophylls (in most cases), as well as the total carbohydrates contents in the different plant parts. Also, most of the fertilization treatments increased the $N$ and $P$ contents in the flowers and roots, as well as the $K$ contents in leaves and stems. Moreover, oil percentage and yield were increased in the flowers and leaves of fertilized plants (compared to the control), with the highest values resulting from plants supplied with $C M$, with or without biofertilization (especially in the second season). Linalool, limonene, ocimene, caryophyllene and eugenol were the main 
components of the oil extracted from Tagetes erecta flowers and leaves. $B$-ionone was also detected at lower percentages in Tagetes erecta oil. Low percentages of $\alpha$-pinene and $\beta$-pinene were identified as oil components in the flowers, but were almost completely absent in oil extracted from the leaves. Also, the percentage of ocimene was generally higher in the oil from flowers than in the oil from leaves. On the other hand, the percentage of eugenol was higher in oil from leaves than in oil from flowers. In general, the different fertilization treatments generally increased the percentages of caryophyllene and eugenol in oil extracted from the flowers. In oil from the leaves, using $N_{1}, N_{2}$ or bio-fertilization increased the ocimene and eugenol percentages, while cattle manure generally increased the limonene and linalool percentages. Also, the limonene, eugenol and $\beta$-ionone percentages in the leaves oil were increased by fertilization using $1 / 2 N_{1}+$ biofertilization, while the $\beta$-pinene and linalool percentages were increased by $N_{1}+$ bio-fertilization. Fertilization with $N_{1}$ gave the highest percentages of eugenol and $\beta$-ionone in oil from the flowers, as well as the highest percentages of ocimene, caryophyllene and eugenol in oil from the leaves.

Conclusively, from the recorded results, it was concluded that the different fertilization treatments had a favourable effect on the growth, flowering, chemical composition and oil production of Tagetes erecta plants, with fertilization using CM giving the best results.

Keywords: Response of summer annual flowering plants, chemical, organic, bio-fertilization, African marigold, tagetes erecta L plants

\section{INTRODUCTION}

The genus Tagetes (Family: Asteraceae) includes about 50 species of erect, bushy, strongly aromatic annuals and herbaceous perennials. Several Tagetes species are found in hot, dry slopes and in valley bottoms in different parts of north and south America; one species occurs in Africa. The many hybrids and cultivars are derived mainly from T. erecta, T. patula and T. tenuifolia. Four main hybrid groups are in cultivation: African marigolds, French marigolds, Afro-French marigolds, and Signet marigolds. African marigolds are compact annuals, derived from $T$. erecta, with angular, hairless stems and pinnate, sparsely glandular leaves, $5-10 \mathrm{~cm}$ long, each with 11-17 narrowly lance-shaped, pointed, sharply toothed leaflets of up to $5 \mathrm{~cm}$ in length. Large, densely double, pompon-like, terminal flower heads, usually to $12 \mathrm{~cm}$ across, each with 5-8 or more ray-florets and numerous orange to yellow disc-florets, are produced from late spring to autumn (Brickell, 1996).

Fertilization is among the most important cultural practices influencing the growth and productivity of herbaceous flowering plants 
(including Tagetes erecta). Also, an increase in the oil yield of Tagetes minuta has obtained as a result of fertilization treatments (Ram et al., 1999). However, the use of chemical fertilizers has been discouraged for many years, due to their undesirable impact on the environment. Chemical fertilization may contribute to aquifer pollution, and to the accumulation of chemical residues in plant tissues that are consumed by humans. Other types of fertilizers, including bio-fertilizers and organic manures, have been suggested as safer alternatives to conventional chemical fertilization. Several researchers have investigated the effect of organic manures on the growth and productivity of ornamental and medicinal plants (Mohamed, 2003) on Catharanthus roseus, Sakr (2005) on Cassia acutifolia, and many others]. Also, the use of biofertilizers, with or withour chemical or organic fertilizers, has been studied by many workers (Abdou and El-Sayed, 2002) on Carum carvi, and Hafez (2003) on Borago officinalis]. Results of such research work have shown that using organic manures has many advantages, including the production of safe horticultural crops, as well as improving a number of soil characteristics (water holding capacity, resistance to compaction, and cation exchange capacity). This makes it possible to use organic manures for improving the quality of poor sandy soil in desert and coastal areas where extensive landscape activities take place. Furthermore, the substitution of chemical fertilization, at least partly, with organic manures or biofertilizers may result in a reduction of production costs.

This study was conducted with the aim of investigating the effect of chemical, organic and bio-ferilization treatments on the growth, chemical composition and oil production of African marigold (Tagetes erecta L.) plants.

\section{MATERIALS AND METHODS}

This study was carried out at the Experimental Nursery of the Ornamental Horticulture Department, Faculty of Agriculture, Cairo University, Giza, during the two successive season of 2000 and 2001, with the aim of investigating the effect of chemical, organic and bio-ferilization treatments on the growth, chemical composition and oil production of Tagetes erecta $\mathrm{L}$. plants.

Seeds of Tagetes erecta L. were obtained from the Nursery of the Ornamental Horticulture Department. On April 1 $1^{\text {st }}, 2000$ and 2001, the seeds were sown in well-prepared seed beds with a loamy clay soil and peatmoss. On $15^{\text {th }}$ May 2000 and 2001, the seedlings, with a height of 5-7 $\mathrm{cm}$, were transplanted into $25-\mathrm{cm}$ clay pots filled with a sandy soil. The physical and chemical characteristics of the sandy potting soil are shown in Table (A). In addition to the control, the different chemical, organic and bio-fertilization treatments included: (1) Nitrogenous fertilization at the rates of 6 or $12 \mathrm{~g}$ ammonium sulphate /pot, (2) Bio-fertilization, (3) Biofertilization $+\mathrm{N}$ fertilization at 3 or $6 \mathrm{~g}$ ammonium sulphate /pot, (4) Cattle 
Table A. Chemical characteristics of the sandy soil used for potting Tagetes erecta L. plants in the 2000 and 2001 seasons.

\begin{tabular}{|c|c|c|c|c|c|c|c|c|c|c|c|c|c|c|c|c|c|}
\hline \multirow{2}{*}{ 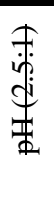 } & \multirow{2}{*}{ 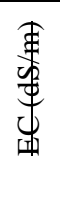 } & \multirow{2}{*}{$\underset{\Phi}{\Phi} \underset{\Phi}{\Phi}$} & \multicolumn{4}{|c|}{$\begin{array}{l}\text { Soluble cations } \\
\text { (meg/L) }\end{array}$} & \multicolumn{4}{|c|}{$\begin{array}{l}\text { Soluble anions } \\
\text { (meg/t) }\end{array}$} & \multicolumn{3}{|c|}{$\begin{array}{l}\text { Macro-nutrients } \\
\text { eontent (ppm) }\end{array}$} & \multicolumn{4}{|c|}{$\begin{array}{l}\text { Micro-nutrients content } \\
(\mathrm{ppm})\end{array}$} \\
\hline & & & $\ddagger_{\oplus}$ & $F_{y_{0}}$ & 市 & + & $\Phi^{\prime}$ & $\underset{\Psi}{\Phi}$ & 可 & $\mathscr{Q}_{1}^{+}$ & N & $\mathrm{P}$ & K & $\mathrm{Fe}$ & $\mathrm{Eu}$ & Zn & $\mathrm{Mn}$ \\
\hline 8.7 & 2.88 & 0.4 & 7.2 & 2.2 & 19 & 0.37 & - & 4 & 13.5 & $\begin{array}{l}14 . \\
27\end{array}$ & 57 & 12 & 96 & 0.62 & 0.16 & $\theta .24$ & 0.28 \\
\hline \multicolumn{18}{|c|}{ Physical separates \% } \\
\hline \multicolumn{3}{|c|}{ Coarse sand } & \multicolumn{4}{|c|}{ Finsand } & \multicolumn{5}{|c|}{ Sillt } & \multicolumn{3}{|c|}{ Elay } & \multicolumn{3}{|c|}{ Elass } \\
\hline \multicolumn{3}{|c|}{83.3} & \multicolumn{4}{|c|}{10.1} & \multicolumn{4}{|c|}{1.1} & & \multicolumn{3}{|c|}{5.5} & \multicolumn{3}{|c|}{ Sandy soil } \\
\hline
\end{tabular}

Table B. The bacterial count of the composite inoculum used for biofertilization of Tagetes erecta L. plants in the 2000 and 2001 seasons.

\begin{tabular}{|c|c|}
\hline Bacteria & Log No. $\mathbf{~ m l}^{\mathbf{1}}$ \\
\hline Total bacterial count & 7.56 \\
Azospirillum brasilense & 6.96 \\
Pseudomonas putida & 7.40 \\
Klebsiella pneumonia & 7.00 \\
\hline
\end{tabular}

Table C. Physical and chemical characteristics of the cattle manure used for fertilization of Tagetes erecta L. plants in the 2000 and 2001 seasons.

\begin{tabular}{|c|c|c|c|c|c|c|c|c|c|c|c|c|c|c|c|c|c|}
\hline \multirow{2}{*}{ 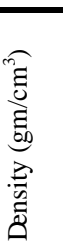 } & \multirow[b]{2}{*}{$\frac{8}{2}$} & \multirow[b]{2}{*}{$\frac{\mathbb{s}}{*}$} & \multirow[b]{2}{*}{$z$} & \multirow[b]{2}{*}{ 焉 } & \multicolumn{4}{|c|}{$\begin{array}{c}\begin{array}{c}\text { Sitikefins } \\
\text { (meqL) }\end{array} \\
\end{array}$} & \multicolumn{3}{|c|}{$\begin{array}{c}\begin{array}{c}\text { Sol o b l e a n i o n s } \\
(\text { meq/L) }\end{array} \\
\end{array}$} & \multicolumn{3}{|c|}{$\begin{array}{c}\begin{array}{c}\text { Maoontinikgatat } \\
(\%)\end{array} \\
\end{array}$} & \multicolumn{3}{|c|}{$\begin{array}{c}\text { Mrontinkontut } \\
\text { (pm) }\end{array}$} \\
\hline & & & & & 晒 & ${ }^{\text {fard }}$ & trz & \pm & 8 & $\sigma$ & $\ddot{q}$ & $\mathrm{~N}$ & $\mathrm{P}$ & $\mathrm{K}$ & $\mathrm{Fe}$ & $\mathrm{Cu}$ & $\mathrm{Zn}$ \\
\hline $\mathrm{OA}$ & 108 & 480 & 780 & 1560 & 480 & 19:4 & 12350 & 360 & 380 & 1280 & 6720 & 000 & 050 & 000 & 60 & 000 & 480 \\
\hline
\end{tabular}

manure at the rate of to $20 \mathrm{~m}^{3} /$ feddan) + bio-fertilization. All the plants in the experiment were $710 \mathrm{~cm}^{3} /$ pot (equivalent to $40 \mathrm{~m}^{3} /$ feddan), or (5) Cattle manure at $355 \mathrm{~cm}^{3} /$ pot (equivalent supplied with chemical phosphorus and potassium (PK) fertilization. Phosphorus fertilization was added to in the form of calcium superphosphate $\left(15.5 \% \mathrm{P}_{2} \mathrm{O}_{5}\right)$, which was mixed into the soil two weeks before planting the seedlings, at the rate of $6 \mathrm{gm} /$ pot. On the other hand, potassium fertilization was added in the form of potassium sulphate (48\% $\mathrm{K}_{2} \mathrm{O}$ ) at the rate of $3 \mathrm{~g} / \mathrm{pot}$, divided into two equal doses, which were applied after 2 and 4 weeks from planting. Plants receiving $\mathrm{N}$ fertilization were supplied with the above-mentioned rates of ammonium sulphate $(20.5 \% \mathrm{~N})$, divided into 3 equal doses applied at 3-week intervals, starting two weeks after transplanting. Plants receiving biofertilization were supplied with a composite 
inoculum (containing Azospirillum brasilense, Klebsiella pneumonia and Pseudomonas putida) in the form of a liquid culture, which was applied at the time of planting at the rate of $10 \mathrm{ml} /$ pot. An additional dose of $10 \mathrm{ml} /$ pot of the liquid culture was applied one month after planting (on $15^{\text {th }}$ June 2000 and 2001). The bacterial count of the composite inoculum (as described by Hegazi et al., 1998) is shown by the data in Table (B). In plants receiving cattle manure (CM) treatments, the tested rates (40 or $20 \mathrm{~m}^{3} /$ feddan) were added to the soil 15 days before planting. The physical and chemical characteristics of the cattle manure used in this experiment are shown in Table (C). Control plants received PK fertilization only. The layout of the experiment was a randomized complete blocks design, with 8 treatments (including the control) and 3 blocks (replicates), each consisting of 5 pots /treatment.

At the termination of each season (on $1^{\text {st }}$ October, 2000 and 2001), data were recorded on plant vegetative growth characterisctics, including plant height $(\mathrm{cm})$, stem diameter $(\mathrm{cm})$ at a height of $5 \mathrm{~cm}$ from the soil surface, number of branches /plant, area $\left(\mathrm{cm}^{2}\right)$ of the $4^{\text {th }}$ leaf from the top of the plant (using a Licor portable area meter, model LI 3000), as well as the fresh and dry weights of leaves, stems and roots /plant. Also, data were recorded on the flowering characteristics, including number of flowers /plant, as well as the fresh and dry weights of flowers /plant. The data recorded on vegetative growth and flowering were statistically analyzed. An analysis of variance (ANOVA) was carried out, and the means were compared using the "Least Significant Difference (LSD)" test at the 0.05 level, as described by Steel and Torrie (1980).

Chemical analysis of fresh leaf samples was also conducted to determine their contents of pigments [chlorophyll "a", chlorophyll "b", total chlorophylls (a+b), carotenoids], using the method described by Saric et al. (1967), while the xanthophyll content was determined using the method outlined by the A.O.A.C. (2000) In addition, samples of leaves, stems, roots and flowers were oven-dried at a temperature of $70^{\circ} \mathrm{C}$ for 24 hours, and their content of total carbohydrates was determined using the method outlined by Dubois et al. (1956). Also, the nutrients were extracted from dried tissue samples (of leaves, stems, roots and flowers) using the method described by Piper (1947), then the nutrient extracts were chemically analyzed to determine their contents of nitrogen (using a modified Micro-Kjeldahl apparatus, as described by Pregl, 1945), phosphorus (using the method described by Jackson (1967), and potassium [using an atomic absorption, flame-photometer (Philips, model PU 9100X), as recommended by Chapman and Pratt (1961)]. At the termination of the second season, the oil (\%) in fresh flower and leaf samples was also determined (using the method outlined in the British Pharmacopoeia, 1963), and the oil yields from flowers and leaves /plant were calculated in proportion to the fresh weight of flowers and leaves. The main components of oil samples from flowers and leaves were then determined by gas liquid chromatographic (GLC) analysis in a GCV Pye Unicam gas-liquid chromatograph equipped with a flame ionizing detector, using the methods described by Bunzen et al. (1969). 


\section{RESULTS AND DISCUSSION}

\section{Vegetative growth \\ 1. Plant height}

The results recorded in (Table 1) show that there was a general increase in the height of plants receiving the different fertilization treatments, compared to the control. However, the effect of most treatments was insignificant in the first season, with only two treatments $\left(1 / 2 \mathrm{~N}_{1}+\right.$ biofertilization, and cattle manure) giving significantly taller plants than the control plants. In the second season, the favourable effect of the fertilization treatments was more pronounced, with all the treatments that included bioor organic (cattle manure) fertilization causing significant increases in plant height, compared to the control. On the other hand, using chemical fertilization alone (i.e., $\mathrm{N}_{1}$ or $\mathrm{N}_{2}$ ) did not significantly increase plant height (in both seasons).

The general increase in plant height as a result of the different fertilization treatments is in agreement with the findings of Dahiya et al. (1998) on African marigold (Tagetes erecta), and Jacoub (1999) on sweet basil (Ocimum basilicum). This increase in plant height may be a result of both the greater number of cells formed and an increased elongation of the individual cells, Marschner (1999).

The data in Table (1) also show that with chemical $\mathrm{N}$ fertilization, substituting half of the used rates with bio-fertilization had some beneficial effect on plant height, i.e., plants receiving the two $\mathrm{N}$ fertilization rates were shorter than those receiving half of the used rates, in combination with biofertilization. However, this effect was statistically insignificant in most cases. The generally favourable effect of combining chemical $\mathrm{N}$ fertilization with bio-fertilization is in agreement with results reported by Chandrikapure et al. (1999) and Gupta et al. (1999) on Tagetes erecta. With organic fertilization, replacing half of the cattle manure rate with the application of bio-fertilization caused a reduction in plant height (which was significant in both seasons).

Among the different fertilization treatments, the most effective one for increasing plant height was supplying the plants with cattle manure, which gave the tallest plants in both seasons, followed by plants supplied with $1 / 2$ $\mathrm{N}_{1}+$ bio-fertilization.

\section{Stem diameter}

The data presented in Table 1 show that in most cases, plants receiving the different fertilization treatments had thicker stems than those of control plants. The only exception to this general trend was recorded in the first season, with plants fertilized using bio-fertilization having insignificantly thinner stems than the control plants. The general increase in 
Table 1. Effect of chemical (NPK), organic and bio-fertilization on vegetative growth characteristics in Tagetes erecta plants during the 2000 and 2001 seasons.

\begin{tabular}{|l|cc|cc|cc|cc|}
\hline \multirow{2}{*}{ reatments } & \multicolumn{2}{|c|}{$\begin{array}{c}\text { Plant height } \\
(\mathbf{c m})\end{array}$} & \multicolumn{2}{c|}{$\begin{array}{c}\text { Stem diameter } \\
\text { (cm) }\end{array}$} & \multicolumn{2}{c|}{$\begin{array}{c}\text { Number of } \\
\text { branches } \\
\text { /plant }\end{array}$} & \multicolumn{2}{c|}{$\begin{array}{c}\text { Leaf area } \\
\left(\mathbf{c m}^{2}\right)\end{array}$} \\
\cline { 2 - 10 } & $\mathbf{2 0 0 0}$ & $\mathbf{2 0 0 1}$ & $\mathbf{2 0 0 0}$ & $\mathbf{2 0 0 1}$ & $\mathbf{2 0 0 0}$ & $\mathbf{2 0 0 1}$ & $\mathbf{2 0 0 0}$ & $\mathbf{2 0 0 1}$ \\
\hline Control & 86.83 & 76.17 & 1.10 & 1.01 & 5.50 & 6.67 & 14.39 & 10.86 \\
$\mathbf{N}_{\mathbf{1}}$ & 97.83 & 87.39 & 1.47 & 1.45 & 11.20 & 11.56 & 26.36 & 29.09 \\
$\mathbf{N}_{\mathbf{2}}$ & 93.50 & 76.33 & 1.48 & 1.62 & 11.33 & 11.17 & 20.30 & 21.25 \\
$\mathbf{B i o}_{1 / 2} \mathbf{N}_{\mathbf{1}}+\mathbf{B i o}$ & 90.89 & 95.83 & 1.07 & 1.13 & 6.28 & 6.83 & 19.10 & 19.58 \\
$\mathbf{N}_{\mathbf{1}}+\mathbf{B i o}$ & 104.30 & 99.00 & 1.97 & 1.27 & 12.50 & 9.92 & 17.74 & 22.42 \\
$\mathbf{C M}$ & 94.33 & 91.17 & 1.93 & 1.63 & 10.50 & 8.17 & 26.13 & 25.34 \\
$\mathbf{1} / \mathbf{C M}+\mathbf{B i o}$ & 116.00 & 108.2 & 2.15 & 1.88 & 14.22 & 12.75 & 23.03 & 16.55 \\
\hline \multicolumn{1}{|c|}{ LSD $(\mathbf{0 . 0 5})$} & 98.00 & 96.03 & 2.30 & 1.92 & 13.50 & 9.83 & 31.31 & 32.12 \\
\hline
\end{tabular}

$\mathrm{N}_{1}$ and $\mathrm{N}_{2}=3$ or $6 \mathrm{~g}$ ammonium sulphate, $\mathrm{CM}=$ Cattle manure, Bio=Bio-fertilization

stem diameter as a result of application of the fertilization treatments is in agreement with the findings of Chandrikapure et al. (1999) on marigold. Also, the recorded data show that, although chemical $\mathrm{N}$ fertilization gave higher values when applied at the high rate $\left(\mathrm{N}_{2}\right)$ than at the low rate $\left(\mathrm{N}_{1}\right)$, the difference between the stem diameters recorded with the two rates were insignificant.

It is also clear from the data in Table 1 that, in most cases, combining bio-fertilization with chemical or organic fertilization gave significantly thicker stems than those obtained when bio-fertilization was used alone. A similar conclusion was reached by Chandrikapure et al. (1999) on marigold. Moreover, when half of the chemical $\mathrm{N}$ fertilization rates were replaced by biofertilization, the stem diameters were either significantly higher (in the first season) or insignificantly different (in the second season) than those obtained from plants receiving $\mathrm{N}$ fertilization only. Also, substituting half the rate of cattle manure with bio-fertlization (i.e., fertilization with $1 / 2 \mathrm{CM}+$ biofertilization) gave stem diameters that were insignificantly different than those obtained in plants supplied with CM (at the full rate) without bio-fertilization. This clearly indicates that combining bio-fertilization with half the rates of chemical $\mathrm{N}$ fertilization or cattle manure was more economical than using the full rates of the two types of fertilizers. The results presented in Table (1) also show that in both seasons, plants fertilized with $1 / 2 \mathrm{CM}+$ bio-fertilization gave the highest stem diameters, followed by plants fertilized using CM. On the other hand, the least effective treatment was using bio-fertilization alone, which had no significant effect on stem diameter, compared to that of control plants.

\section{Number of branches/plant}

The results recorded in the two seasons (Table 1) show that the number of branches formed by Tagetes erecta plants was generally increased by the 
different fertilization treatments. This promotion in branching of fertilized plants is in agreement with results reported by Ram et al. (1999) on T. minuta, and Sakr (2005) on Cassia acutifolia Delile plants.

Among the different fertilization treatments, fertilization using cattle manure gave the highest number of branches/plant (in both seasons). The beneficial effect of organic fertilization on branching is in agreement with the findings of Yadav and Singh (1997) on Tagetes erecta. In contrast, using biofertilization without chemical $\mathrm{N}$ fertilization or organic manure was the least effective treatment for increasing the number of branches, as it gave insignificantly higher values than the control (in both seasons). In most cases, combining bio-fertilization with the application of chemical $\mathrm{N}$ fertilization or cattle manure caused significant increases in the number of branches/plant, compared to values obtained with bio-fertilization alone. The favourable effect of combining bio-fertilization with chemical $\mathrm{N}$ fertilization is in agreement with the findings of Chandrikapure et al. (1999) on marigold.

It is also clear that, in most cases, substituting half of the chemical $\mathrm{N}$ fertilization rates with bio-fertilization (i.e. supplying the plants with $1 / 2 \mathrm{~N}_{1}+$ bio-fertilization instead of $\mathrm{N}_{1}$, or $\mathrm{N}_{1}+$ bio-fertilization instead of $\mathrm{N}_{2}$ ) had no significant effect on the number of branches/plant, compared to that formed by plants receiving the full rates of chemical $\mathrm{N}$ fertilization. Also, in the first season, plants fertilized with half of the cattle manure rate combined with biofertilization (i.e., $1 / 2 \mathrm{CM}+$ bio-fertilization), had an insignificantly lower number of branches, compared to plants supplied with cattle manure without bio-fertilization. However, a significant decrease in the number of branches was recorded in the second season when half of the cattle manure rate was replaced by bio-fertilization.

\section{Leaf area}

The results recorded in the two seasons (Table 1) show that in general, leaf area was increased by supplying the plants with the different fertilization treatments, compared to the control. This promotion of leaf size as a result of fertilization treatments was more pronounced in the second season, with only one treatment (viz., CM) causing an insignificant increase in leaf area, whereas all other treatments increased it significantly, compared to the control. Among the different treatments, fertilization using a mixture of organic manure and bio-fertilization (i.e., fertilization with $1 / 2 \mathrm{CM}+$ bio-fertilization) gave the highest values in both seasons, followed by fertilization using $\mathrm{N}_{1}$. On the other hand, the least effective treatment in increasing leaf size in the first season was $1 / 2 \mathrm{~N}_{1}+$ bio-fertilization, whereas in the second season the least effective treatment was CM.

The data in Table (1) also show that when chemical $\mathrm{N}$ fertilization was used without bio-fertilization, the low $\mathrm{N}$ rate $\left(\mathrm{N}_{1}\right)$ was more effective than the high rate $\left(\mathrm{N}_{2}\right)$. However, when half of the $\mathrm{N}$ rates were substituted by biofertilization, the high $\mathrm{N}$ rate was more effective than the low rate (i.e., $\mathrm{N}_{1}+$ bio- 
fertilization gave larger leaves than $1 / 2 \mathrm{~N}_{1}+$ biofertilization). Combining cattle manure (at half the full rate) with bio-fertilization also gave significantly larger leaves than using cattle manure (at the full rate) with no bio-fertilization.

\section{Fresh and dry weights of leaves/plant}

The results presented in Table 2 show that in both seasons, the fresh and dry weights of leaves/plant were significantly increased by the different fertilization treatments. It is also clear from the data in Table 2 that, in general, chemical $\mathrm{N}$ fertilization (with or without bio-fertilization) gave lower values than those obtained from plants fertilized using cattle manure (with or without bio-fertilization). In fact, plants supplied with cattle manure (CM) gave the highest values in both seasons, followed by plants fertilized using $1 / 2 \mathrm{CM}+$ biofertilization. In both seasons, no significant difference was detected between the dry weights of leaves formed on plants receiving these two treatments. On the other hand, the least effective treatment for increasing the fresh and dry weights of leaves was the application of bio-fertilization without chemical $\mathrm{N}$ fertilization or cattle manure. The data in Table 2, also show that when chemical $\mathrm{N}$ fertilization was used without bio-fertilization, the low $\mathrm{N}$ rate $\left(\mathrm{N}_{1}\right)$ gave generally higher values than the high rate $\left(\mathrm{N}_{2}\right)$. However, when chemical $\mathrm{N}$ fertilization was combined with bio-fertilization, an opposite trend was recorded, i.e., $\mathrm{N}_{1}+$ bio-fertilization gave higher values than $1 / 2 \mathrm{~N}_{1}+$ biofertilization. With organic fertilization, using cattle manure without biofertilization gave significantly heavier fresh leaves than those obtained when half of the cattle manure rate was replaced by bio-fertilization, whereas the difference in leaves dry weights was insignificant (in both seasons).

\section{Fresh and dry weights of stems /plant}

The data presented in Table 2 show that most of the fertilization treatments significantly increased the fresh and dry weights of stems/plant in both seasons, compared to the control plants. In both seasons, organic fertilization (with or without bio-fertilization) was generally more effective for increasing the stems fresh and dry weights, compared to using chemical $\mathrm{N}$ fertilization. In fact, fertilization using cattle manure (CM) gave the highest fresh and dry weights of stems (in both seasons), followed by $1 / 2 \mathrm{CM}+$ biofertilization. On the other hand, the least effective treatment was fertilization using bio-fertilization without any chemical $\mathrm{N}$ or organic manure, which gave insignificantly higher values than those obtained from control plants. Also, fertilization with $\mathrm{N}_{1}$ caused only a slight (insignificant) increase in the dry weight of stems, compared to the control (in both seasons). Moreover, supplying the plants with $\mathrm{N}_{1}+$ bio-fertilization had no significant effect on the dry weight of stems in the first season, while $\mathrm{N}_{2}$ had no significant effect in the second season. The data in Table 2, also show that in most cases, replacing half of the chemical $\mathrm{N}$ fertilization rates with bio-fertilization significantly increased the fresh weight of stems, especially in the second season, compared to using the whole rates of $\mathrm{N}$ (without bio-fertilization). On the other hand, the stems 
dry weight was not significantly affected by replacing half of the chemical $\mathrm{N}$ rates with bio-fertilization (in both seasons). With organic fertilization, substituting half of the cattle manure rate with bio-fertilization caused a reduction in the fresh and dry weights of stems.

\section{Fresh and dry weights of roots /plant}

The data presented in Table 2 show that the fresh and dry weights of roots were not significantly affected by the application of bio-fertilization (without chemical $\mathrm{N}$ fertilization or cattle manure), compared to the control plants. On the other hand, most of the other fertilization treatments significantly increased the roots fresh, compared to the control (in both seasons). The roots dry weight was also generally increased by the different fertilization treatment, compared to the control, but the increase was insignificant in many cases. It is also clear from the data in Table 2 that organic fertilization using cattle manure (especially when applied at the full rate without bio-fertilization) was generally more effective than chemical $\mathrm{N}$ fertilization. In both seasons, fertilization with cattle manure gave significantly higher roots fresh and dry weights than those obtained from control plants. Moreover, this treatment appeared to be the most effective treatment, as it gave the highest roots fresh weight in the second season, as well as the highest roots dry weight in both seasons. The results recorded in the two seasons also showed that in most cases, substituting half the rates of chemical $\mathrm{N}$ fertilization or cattle manure with bio-fertilization did not cause significant changes in the fresh or dry weights of roots, compared to those obtained when the full fertilization rates were used without bio-fertilization. The above results are in agreement with the findings of Mohamed (2003) on periwinkle, and Sakr (2005) on Cassia acutifolia plants.

\section{Flowering}

\section{Number of flowers /plant}

The results recorded in the two seasons (Table 3) show that the number of flowers /plants was significantly increased by the different fertilization treatments. Similar increases in flower production by Tagetes erecta plants as a result of fertilization treatments have been reported by Arulmozhiyan and Pappaiah (1989). Among the plants receiving chemical $N$ fertilization, those that were supplied with $1 / 2 \mathrm{~N}_{1}+$ bio-fertilization gave the highest number of flowers in both seasons. The beneficial effect of combining bio-fertilization with chemical $\mathrm{N}$ fertilization on flower production is in agreement with the findings of Chandrikapure et al. (1999) on marigold. The data presented in Table 2, also show that supplying Tagetes erecta plants with cattle manure (CM), with or without bio-fertilization, was generally more effective than chemical $\mathrm{N}$ fertilization (with or without bio-fertilization) for increasing the production of flowers. In both seasons, the highest values were obtained from plants fertilized with $1 / 2 \mathrm{CM}+$ bio-fertilization, followed by plants fertilized using $\mathrm{CM}$. 
Table 3. Effect of chemical (NPK), organic and bio-fertilization on flowering characteristics in Tagetes erecta plants during the 2000 and 2001 seasons.

\begin{tabular}{|c|c|c|c|c|c|c|}
\hline \multirow[t]{2}{*}{ Treatments } & \multicolumn{2}{|c|}{$\begin{array}{c}\text { Number of flowers } \\
\text { /plant }\end{array}$} & \multicolumn{2}{|c|}{$\begin{array}{l}\text { Flowers fresh weight } \\
\text { (g/plant) }\end{array}$} & \multicolumn{2}{|c|}{$\begin{array}{c}\text { Flowers dry weight } \\
\text { (g/plant) }\end{array}$} \\
\hline & 2000 & 2001 & 2000 & 2001 & 2000 & 2001 \\
\hline Control & 116.3 & 90.33 & 140.3 & 97.2 & 17.23 & 16.22 \\
\hline $\mathbf{N}_{1}$ & 195.0 & 165.7 & 247.1 & 221.0 & 35.91 & 34.52 \\
\hline $\mathbf{N}_{2}$ & 263.7 & 152.0 & 401.2 & 130.8 & 57.11 & 17.25 \\
\hline Bio & 225.3 & 136.7 & 311.9 & 230.0 & 43.54 & 35.39 \\
\hline $1 / 2 N_{1}+B i o$ & 309.0 & 212.0 & 348.2 & 274.2 & 48.74 & 55.21 \\
\hline$N_{1}+B i o$ & 258.0 & 145.7 & 342.2 & 192.8 & 48.29 & 24.16 \\
\hline CM & 336.7 & 200.3 & 387.9 & 291.1 & 59.38 & 42.72 \\
\hline 1/2 CM + Bio & 383.0 & 230.5 & 490.9 & 241.6 & 69.73 & 27.34 \\
\hline LSD $(0.05)$ & 39.7 & 31.2 & 23.3 & 45.5 & 33.75 & 18.81 \\
\hline
\end{tabular}

\section{Fresh and dry weights of flowers/plant}

The results recorded in the two seasons (Table 3) show that in both seasons, the fresh and dry weights of flowers were increased by the different fertilization treatments. However, the favourable effect of fertilization was more pronounced on the flowers fresh weight than on their dry weight. In both seasons, most of the fertilization treatments caused significant increases in the fresh weight of flowers, compared to the control. On the other hand, the effect of the fertilization treatments on the flowers dry weight was insignificant in many cases, especially with treatments that did not include organic fertilization (using cattle manure). In general, the addition of cattle manure (with or without biofertilization) was more effective for increasing the fresh and dry weights of flowers, compared to the application of chemical $\mathrm{N}$ fertilization. In the first season, the highest fresh and dry weights of flowers/plant were obtained from plants fertilized using a mixture of cattle manure and bio-fertilization (i.e., $1 / 2 \mathrm{CM}$ + bio-fertilization). In the second season the highest flowers fresh weight was obtained from plants fertilized using cattle manure without bio-fertilization, while the highest flowers dry weight was obtained from plants fertilized using $1 / 2 \mathrm{~N}_{1}+$ bio-fertilization, followed by plants fertilized using CM.

\section{Chemical composition}

\section{Leaf pigments content}

\section{a. Chlorophyll ( $a$, b and total chlorophylls) content}

Results of chemical analysis of fresh leaf samples (Table 4) have shown that the contents of chlorophyll "a", chlorophyll " $\mathrm{b}$ " and total chlorophylls in leaves of Tagetes erecta were generally increased by the different fertilization treatments. Similar increases in the chlorophyll content of T. erecta leaves have been reported by Yadav et al. (1999) as a result of $\mathrm{N}$ fertilization treatments. In the first season, some exceptions to this general trend were detected. For example, the chlorophyll "a" content was decreased (compared to the control) as 
a result of supplying the plants with $1 / 2 \mathrm{~N}_{1}+$ bio-fertilization, while the chlorophyll " $b$ " content was decreased in plants fertilized using $\mathrm{N}_{1}, \mathrm{~N}_{1}+$ biofertilization, or CM. Also, the total chlorophylls $(a+b)$ content was decreased in the first season as a result of fertilization using $1 / 2 \mathrm{~N}_{1}+$ bio-fertilization, or CM. In the second season, the favourable effect of the fertilization treatments on chlorophyll synthesis and accumulation was more pronounced. Only one treatment $\left(1 / 2 \mathrm{~N}_{1}+\right.$ bio-fertilization) decreased the chlorophyll " $\mathrm{b}$ " content in the second season, whereas all other treatments increased the chlorophyll "a", chlorophyll "b" and total chlorophylls contents, compared to the control. The data in Table 4, also show that in most cases, the effect of $\mathrm{N}$ fertilization on the chlorophyll content was greater at the high $\mathrm{N}$ rate than at the low rate (with or without bio-fertilization). Moreover, the effect of $\mathrm{N}$ fertilization was generally greater when $\mathrm{N}$ was applied at the full rates without bio-fertilization, compared to using it at half rates in combination with bio-fertilization. In contrast, the effect of cattle manure was more pronounced (in most cases) when it was used at half rate in combination with bio-fertilization, compared to using it at full rate without biofertilization.

\section{b. Carotenoids content}

The data in Table 4 show that in both seasons, most of the fertilization treatments increased the carotenoids content, compared to that of control plants. There were a few exceptions to this general trend. For example, plants fertilized using $1 / 2 \mathrm{~N}_{1}+$ bio-fertilization had lower carotenoids contents than the control (in both easons). Also, supplying the plants with $1 / 2 \mathrm{CM}+$ bio-fertilization decreased the carotenoids content in the second season, compared to the control.

The results presented in Table 4, also show that in both seasons, the highest carotenoids content was found in the leaves of plants fertilized using $\mathrm{N}_{1}+$ bio-fertilization, followed by plants fertilized using $\mathrm{N}_{2}$.

\section{c. Xanthophyll content}

The xanthophyll content was considerably affected by the different fertilization treatments (Table 4). In both seasons, most of the treatments increased the xanthophyll content, compared to that of control plants. Only two treatments $\left(\mathrm{N}_{1}+\right.$ bio-fertilization, and cattle manure) gave lower xanthophyll contents in both seasons than the control.

The data in Table 4, also show that chemical $\mathrm{N}$ fertilization gave generally higher values when applied at the low rate than at the high rate, especially when chemical fertilization was combined with bio-fertilization. Also, using cattle manure (CM) at half rate in combination with bio-fertilization gave higher values than those obtained from plants supplied with $\mathrm{CM}$ alone at the full rate.

Among the different treatments, the most effective one for increasing the xanthophylls content was supplying the plants with $1 / 2 \mathrm{CM}+$ bio-fertilization). Plants receiving this treatment gave the highest values in both seasons, followed by plants supplied with $1 / 2 \mathrm{~N}_{1}+$ bio-fertilization). On the other hand, the lowest 
values were obtained from plants fertilized with $\mathrm{CM}$, followed by plants fertilized with $\mathrm{N}_{1}+$ bio-fertilization.

\section{Total carbohydrates contents in leaves, stems, roots and flowers:}

Chemical analysis of the different plant parts has shown that in most cases, the different fertilization treatments increased the total carbohydrates contents in the leaves, stems, flowers and roots, compared to those of the control plants (Table 5). The generally favourable effect of the fertilization treatments on the synthesis and accumulation of carbohydrates in plant tissues is in agreement with the results reported by Gouda (2002) on Amaranthus tricolor, and Sakr (2005) on Cassia acutifolia. Among the different treatments, the combination of bio-fertilization and cattle manure (i.e., $1 / 2 \mathrm{CM}+$ bio-fertilization) was generally the most effective treatment for increasing the carbohydrate contents in the different plant parts. In the first season, plants receiving this treatment had the highest carbohydrate contents in the leaves, stems and roots. Also, in the second season this treatment gave the highest carbohydrate contents in the stems, roots and flowers. On the other hand, fertilization using $\mathrm{N}_{1}+$ bio-fertilization gave the highest carbohydrates content in the leaves in the second season, as well the highest carbohydrates content in the flowers in the first season. In contrast, using bio-fertilization alone decreased the carbohydrates content of the leaves in both seasons, as well as the carbohydrates content of the stems in the first season, compared to the control. Also, fertilization using $\mathrm{N}_{1}+$ bio-fertilization decreased the carbohydrates content of the roots in the second season, while $\mathrm{N}_{2}$ decreased the carbohydrates content of the flowers in the first season, compared to the control.

Table 5. Effect of chemical (NPK), organic and bio-fertilization on the total carbohydrates (\% D.W.) in the leaves, stems, flowers and roots of Tagetes erecta plants during the 2000 and 2001 seasons.

\begin{tabular}{|l|cc|cc|cc|cc|}
\hline \multirow{2}{*}{ Treatments } & \multicolumn{8}{|c|}{ Total carbohydrates (\% D.W.) } \\
\cline { 2 - 10 } & \multicolumn{2}{|c|}{ Leaves } & \multicolumn{2}{c|}{ Stems } & \multicolumn{2}{c|}{ Roots } & \multicolumn{2}{c|}{ Flowers } \\
\cline { 2 - 9 } & $\mathbf{2 0 0 0}$ & $\mathbf{2 0 0 1}$ & $\mathbf{2 0 0 0}$ & $\mathbf{2 0 0 1}$ & $\mathbf{2 0 0 0}$ & $\mathbf{2 0 0 1}$ & $\mathbf{2 0 0 0}$ & $\mathbf{2 0 0 1}$ \\
\hline Control & 11.29 & 15.36 & 10.52 & 7.27 & 9.03 & 13.48 & 7.23 & 6.33 \\
$\mathbf{N}_{\mathbf{1}}$ & 12.60 & 17.05 & 12.33 & 13.26 & 14.50 & 15.81 & 10.91 & 8.50 \\
$\mathbf{N}_{\mathbf{2}}$ & 10.05 & 16.20 & 11.90 & 10.20 & 13.70 & 13.72 & 6.15 & 10.15 \\
$\mathbf{B i o}$ & 9.55 & 12.21 & 9.50 & 10.33 & 14.40 & 11.63 & 7.88 & 12.16 \\
$\mathbf{1} / \mathbf{2} \mathbf{N}_{\mathbf{1}}+\mathbf{B i o}$ & 14.60 & 14.50 & 15.33 & 13.99 & 20.80 & 18.54 & 15.22 & 15.27 \\
$\mathbf{N}_{\mathbf{1}}+\mathbf{B i o}$ & 16.64 & 20.12 & 18.00 & 12.10 & 18.11 & 11.34 & 16.02 & 12.38 \\
$\mathbf{C M}$ & 16.91 & 16.35 & 17.50 & 11.80 & 15.23 & 17.12 & 13.23 & 14.49 \\
$\mathbf{1} \mathbf{2} \mathbf{C M}+\mathbf{B i o}$ & 22.82 & 19.46 & 20.18 & 14.11 & 21.05 & 20.99 & 15.49 & 16.50 \\
\hline
\end{tabular}

$\mathrm{N}_{1}$ and $\mathrm{N}_{2}=3$ or $6 \mathrm{~g}$ ammonium sulphate, $\mathrm{CM}=$ Cattle manure, Bio $=$ Bio-fertilization

\section{Nutrient percentage in leaves, stems, flowers and roots: a. Nitrogen}

The data presented in Table 6 show that in both seasons, the $\mathrm{N}$ percent of the leaves was decreased by the different fertilization treatments, whereas 
Table 6. Effect of chemical (NPK), organic and bio-fertilization on the nitrogen, phosphorus and potassium percentage (D.W.) in the leaves, stems, flowers and roots of Tagetes erecta plants during the 2000 and 2001 seasons.

\begin{tabular}{|c|c|c|c|c|c|c|}
\hline \multirow{2}{*}{ Treatments } & \multicolumn{2}{|c|}{ Nitrogen } & \multicolumn{2}{|c|}{ Phosphorus } & \multicolumn{2}{|c|}{ Potassium } \\
\hline & 2000 & 2001 & 2000 & 2001 & 2000 & 2001 \\
\hline $\begin{array}{l}\text { Control } \\
N_{1} \\
N_{2} \\
\text { Bio } \\
1 / 2 N_{1}+\text { Bio } \\
N_{1}+\text { Bio } \\
\text { CM } \\
1 / 2 C M+\text { Bio }\end{array}$ & $\begin{array}{l}2.76 \\
1.84 \\
2.12 \\
2.32 \\
2.44 \\
1.96 \\
1.52 \\
1.68\end{array}$ & $\begin{array}{l}2.84 \\
2.14 \\
2.28 \\
1.56 \\
1.76 \\
1.66 \\
1.48 \\
1.40\end{array}$ & $\begin{array}{l}\underline{\text { Leav }} \\
0.138 \\
0.103 \\
0.123 \\
0.129 \\
0.132 \\
0.115 \\
0.106 \\
0.110\end{array}$ & $\begin{array}{l}0.150 \\
0.124 \\
0.137 \\
0.109 \\
0.112 \\
0.114 \\
0.090 \\
0.088\end{array}$ & $\begin{array}{l}1.59 \\
1.89 \\
1.76 \\
2.67 \\
2.27 \\
2.30 \\
2.40 \\
2.06\end{array}$ & $\begin{array}{l}1.79 \\
2.23 \\
1.83 \\
2.10 \\
1.96 \\
2.36 \\
1.65 \\
2.71\end{array}$ \\
\hline $\begin{array}{l}\text { Control } \\
N_{1} \\
N_{2} \\
\text { Bio } \\
1 / 2 N_{1}+\text { Bio } \\
N_{1}+\text { Bio } \\
\text { CM } \\
1 / 2 C M+\text { Bio }\end{array}$ & $\begin{array}{l}1.36 \\
1.20 \\
0.88 \\
1.20 \\
1.12 \\
1.68 \\
1.00 \\
1.44 \\
\end{array}$ & $\begin{array}{l}1.20 \\
1.04 \\
1.60 \\
1.36 \\
1.24 \\
1.52 \\
1.36 \\
1.20 \\
\end{array}$ & $\begin{array}{l}\text { Sten } \\
0.051 \\
0.052 \\
0.046 \\
0.048 \\
0.046 \\
0.053 \\
0.047 \\
0.050\end{array}$ & $\begin{array}{l}0.068 \\
0.062 \\
0.068 \\
0.051 \\
0.050 \\
0.069 \\
0.062 \\
0.060\end{array}$ & $\begin{array}{l}1.76 \\
1.72 \\
1.48 \\
2.30 \\
2.03 \\
2.38 \\
2.27 \\
2.47 \\
\end{array}$ & $\begin{array}{l}1.66 \\
2.06 \\
1.52 \\
2.14 \\
1.72 \\
2.16 \\
3.24 \\
2.67 \\
\end{array}$ \\
\hline $\begin{array}{l}\text { Control } \\
N_{1} \\
N_{2} \\
\text { Bio } \\
1 / 2 N_{1}+\text { Bio } \\
N_{1}+\text { Bio } \\
\text { CM } \\
1 / 2 C M+\text { Bio }\end{array}$ & $\begin{array}{l}1.30 \\
0.94 \\
1.66 \\
1.01 \\
1.22 \\
1.94 \\
1.80 \\
1.66 \\
\end{array}$ & $\begin{array}{l}1.15 \\
1.44 \\
1.08 \\
1.94 \\
1.51 \\
1.15 \\
1.30 \\
1.22 \\
\end{array}$ & $\begin{array}{l}0.051 \\
0.044 \\
0.057 \\
0.047 \\
0.053 \\
0.064 \\
0.056 \\
0.054\end{array}$ & $\begin{array}{l}0.051 \\
0.056 \\
0.049 \\
0.065 \\
0.058 \\
0.051 \\
0.053 \\
0.051 \\
\end{array}$ & $\begin{array}{l}1.14 \\
1.44 \\
1.87 \\
1.10 \\
1.29 \\
1.56 \\
1.48 \\
1.26 \\
\end{array}$ & $\begin{array}{l}1.67 \\
1.75 \\
1.72 \\
1.71 \\
1.26 \\
1.36 \\
1.02 \\
1.09 \\
\end{array}$ \\
\hline $\begin{array}{l}\text { Control } \\
N_{1} \\
N_{2} \\
\text { Bio } \\
1 / 2 N_{1}+\text { Bio } \\
N_{1}+\text { Bio } \\
\text { CM } \\
1 / 2 \mathrm{CM}+\text { Bio }\end{array}$ & $\begin{array}{l}1.12 \\
1.08 \\
1.40 \\
1.48 \\
1.24 \\
1.36 \\
1.84 \\
1.92\end{array}$ & $\begin{array}{l}1.16 \\
1.36 \\
1.44 \\
1.72 \\
1.40 \\
1.48 \\
1.56 \\
1.40\end{array}$ & $\begin{array}{l}\underline{\text { Flow }} \\
0.077 \\
0.084 \\
0.081 \\
0.101 \\
0.107 \\
0.115 \\
0.116 \\
0.128\end{array}$ & $\begin{array}{l}0.105 \\
0.124 \\
0.126 \\
0.150 \\
0.151 \\
0.155 \\
0.159 \\
0.149\end{array}$ & $\begin{array}{l}1.83 \\
1.93 \\
1.98 \\
1.87 \\
1.70 \\
1.80 \\
1.75 \\
1.47\end{array}$ & $\begin{array}{l}1.50 \\
1.65 \\
1.87 \\
1.67 \\
1.42 \\
1.29 \\
1.24 \\
1.37\end{array}$ \\
\hline
\end{tabular}

$\mathrm{N}_{1}$ and $\mathrm{N}_{2}=3$ or $6 \mathrm{~g}$ ammonium sulphate,

$\mathrm{CM}=$ Cattle manure,

Bio $=$ Bio-fertilization

the $\mathrm{N}$ percent of the flowers was generally increased, compared to that of control plants. In both seasons, control plants had the highest $\mathrm{N}$ percent in their leaves, compared to plants receiving any of the tested fertilization treatments. 
On the other hand, the effect of the fertilization treatments on the $\mathrm{N}$ percent of the stems differed from one season to the other, since most of the treatments decreased it in the first season, and increased it in the second season, compared to the control. The only treatment which increased the $\mathrm{N}$ percent of the stems in the two seasons was fertilization using $\mathrm{N}_{1}+$ bio-fertilization. In both seasons, the $\mathrm{N}$ percent in the stems of plants receiving this treatment was higher than that of plants receiving any other treatment.

Regarding the $\mathrm{N}$ content of the roots, the data in Table 6 show that in the first season, the various fertilization treatments had different effects on the recorded values, with three treatments (viz. $\mathrm{N}_{1}$, bio-fertilization alone, and $1 / 2 \mathrm{~N}_{1}$ + bio-fertilization) causing decreases in the $\mathrm{N}$ percent, whereas the other four treatments increased it, compared to the control. In the second season, the favourable effect of the fertilization treatments on the $\mathrm{N}$ percent of roots was more evident, with only one treatment (viz., $\mathrm{N}_{2}$ ) causing a reduction in the recorded values, while plants receiving any of the other treatments had higher $\mathrm{N}$ percent in their roots, compared to control plants.

The general increases in the $\mathrm{N}$ percent of flowers and roots (especially in the second season) is in agreement with the findings of Anuradha et al. (1988), who reported that the $\mathrm{N}$ percent of Tagetes erecta plants was increased significantly with increasing $\mathrm{N}$ and $\mathrm{P}$ application rates.

\section{b. Phosphorus}

It is clear from the data in Table 6 that, in both seasons, the phosphorus percent in the leaves was decreased by the different fertilization treatments, compared to the control. Also, most of the tested treatments decreased the phosphorus content in the stems, with only one treatment (viz. $\mathrm{N}_{1}+$ biofertilization) giving higher values in both seasons than the control.

On the other hand, most of the treatments increased the $\mathrm{P}$ percent in the roots, compared to the control. In the first season, the highest $\mathrm{P}$ content in the roots was found in plants fertilized using $\mathrm{N}_{1}+$ bio-fertilization, whereas in the second season, the highest value was obtained from plants fertilized using biofertilization with no chemical $\mathrm{N}$ fertilization or organic manure. The favourable effect of the fertilization treatments on the $\mathrm{P}$ percent was most apparent in the flowers, with all treatments giving higher values than the control (in both seasons). Treatments that included organic manures were generally more effective in increasing the $\mathrm{P}$ percent of the flowers, compared to chemical $\mathrm{N}$ fertilization, especially when $\mathrm{N}$ fertilization was applied without biofertilization. In the first season, the highest $\mathrm{P}$ percent in flowers was obtained when the plants were fertilized using $1 / 2 \mathrm{CM}+$ bio-fertilization, whereas the highest value in the second season was recorded in plants fertilized with CM.

The general increase in the $\mathrm{P}$ content of roots and flowers as a result of the fertilization treatments is in agreement with the findings of Anuradha et al. (1988) on Tagetes erecta. These results are a clear indication of the important role played by phosphorus in root formation and flowering. 


\section{c. Potassium}

The data presented in (Table 6) show that most of the tested fertilization treatments increased the K percent in leaves and stems of Tagetes erecta plants, compared to the control. Moreover, the $\mathrm{K}$ percent in the roots was increased in both seasons as a result of applying chemical $\mathrm{N}$ fertilization without biofertilization (i.e., application of $\mathrm{N}_{1}$ or $\mathrm{N}_{2}$ ), whereas all other treatments gave different results in the two seasons. Addition of chemical $\mathrm{N}$ fertilization without bio-fertilization also increased the $\mathrm{K}$ percent in flowers (in both seasons), compared to the control, with plants fertilized using $\mathrm{N}_{2}$ giving the highest values in the two seasons. The $\mathrm{K}$ percent of flowers was also increased by biofertilization (without any chemical $\mathrm{N}$ fertilization or organic manure). The above results confirm the results reported by Anuradha et al. (1988), who found that the $\mathrm{K}$ content of Tagetes erecta plants was significantly increased with increasing $\mathrm{N}$ application rates.

In contrast, the $\mathrm{K}$ percent of flowers was decreased in both seasons (compared to the control) when bio-fertilization was combined with chemical $\mathrm{N}$ fertilization or organic manure, or when the plants were fertilized with cattle manure (without bio-fertilization).

\section{Oil production}

\section{In flowers}

The results recorded in the two seasons (Table 7) show that supplying the plants with chemical $\mathrm{N}$ fertilization (without bio-fertilization) decreased the oil percentage in the leaves in both seasons, compared to the control. In contrast, most of the other treatments gave higher values than the control, especially in the first season.

The favourable effect of the fertilization treatments on the oil yield of flower /plant was generally more pronounced than their effect on the oil percentage. In most cases, the different fertilization treatments gave higher oil yields from the leaves than the control plants. Among the different treatments, supplying the plants with $1 / 2 \mathrm{~N}_{1}+$ bio- fertilization gave the highest oil percentage and highest oil yield of flowers /plant in the first season, whereas the highest values recorded in the second season were obtained from plants fertilized with $1 / 2 \mathrm{CM}+$ bio-fertilization. Increases of up to $483 \%$ and $308 \%$ in the oil yield of flowers /plant were recorded as a result of the fertilization treatments in the first and second seasons, respectively. This increase in the oil yield of flowers /plant can be mainly attributed to the increase in the fresh weight of flowers of plants receiving the fertilization treatments. Also, in many cases the increase in oil percentage in flowers contributed to the increase in oil yield of flowers/plant.

\section{In leaves}

It can be seen from the data in Table 7 that all the tested fertilization treatments caused considerable increases in the oil percentage and oil yield of leaves, compared 
to the control. This increase in the oil yield as a result of fertilization treatments is in agreement with the findings of Ram et al. (1999) on Tagetes minuta.

In the first season, the highest oil percentage was recorded in the leaves of plants fertilized with $\mathrm{N}_{2}$, or $1 / 2 \mathrm{CM}+$ bio-fertilization, whereas the highest oil percentage in the second season was obtained in leaves of plants fertilized with $1 / 2 \mathrm{~N}_{1}+$ bio-fertilization.

In general, the effect of the fertilization treatments was more pronounced on the oil yield of leaves than on the oil percentage. It is also clear from the data in Table 7 that in both seasons, treatments including the use of cattle manure, with or without bio-fertilization, were generally more effective than the other treatments for increasing the oil yield of leaves /plant. In both seasons, the highest oil yield of leaves /plant was obtained from plants supplied with cattle manure (which gave increases of $771 \%$ and $1045 \%$ in the first and second seasons, respectively, compared to the control), followed by plants fertilized using $1 / 2 \mathrm{CM}+$ bio-fertilization. A similar trend was observed for the effect of fertilization treatments on the fresh weight of leaves (as previously discussed). This indicates that the main factor influencing the oil yield was the increase in fresh weight of leaves as a result of the fertilization treatments.

\section{Oil composition}

It is clear from the data in Table 8 and Figures (1-5) that ocimene, linalool, limonene, and caryophyllene were the main components of the oil extracted from Tagetes erecta flowers and leaves. Lower percentages of eugenol, $\beta$-ionone, $\alpha$-pinene and $\beta$-pinene were also detected in Tagetes erecta oil. It can also be seen from the data in Table 8 that the composition of oil extracted from the flowers was different than that of oil extracted from the leaves. For example, $\alpha$-pinene and $\beta$-pinene were identified as oil components in the flowers, but were almost completely absent in oil extracted from the leaves. Also, the percentage of ocimene was generally higher in the oil from flowers than in the oil from leaves (as reported by Rao et al. (1999), on Tagetes minuta). On the other hand, the percentage of eugenol was generally higher in oil from leaves than in oil from flowers.

Regarding the effect of the tested fertilization treatments on the composition of oil samples extracted from Tagetes erecta leaves and flowers, the most important results can be summarized as follows:

\section{a- Effect of treatments on oil composition in flowers}

The data presented in Table 8 and Figure 1 show that in most cases, oil extracted from flowers of control plants had higher contents of $\alpha$-pinene, $\beta$ pinene, linalool and ocimene, compared to oil from flowers of plants receiving the different fertilization treatments. A few exceptions to this general trend were detected. For example, oil from flowers of plants supplied with $\mathrm{N}_{2}$ or $1 / 2$ $\mathrm{CM}+$ bio-fertilization had higher percentages of $\beta$-pinene than oil from flowers of control plants. Also, fertilization with $\mathrm{N}_{1}+$ bio-fertilization gave a higher ocimene percentage than that found in oil from control plants. 
On the other hand, the tested fertilization treatments had a generally favourable effect on the percentages of caryophyllene and eugenol, as most of the treatments (especially those containing no cattle manure) gave higher percentages of these oil components than those obtained in oil from control plants. Among the different treatments, supplying the plants with $\mathrm{N}_{1}$ gave the highest percentages of eugenol and $\beta$-ionone (Figure 2), while using biofertilization alone gave the highest limonene and caryophyllene percentages, and fertiliztion with $\mathrm{N}_{1}+$ bio-fertilization gave the highest ocimene percentage (Figure 3).

\section{b- Effect of treatments on oil composition in leaves}

Analysis of oil samples extracted from leaves of Tagetes erecta plants (Table 8) has revealed that fertilizing the plants using $\mathrm{N}_{1}, \mathrm{~N}_{2}$ or bio-fertilization increased the ocimene and eugenol percentages, but decreased the limonene and linalool percentages, compared to those found in the oil distilled from leaves of control plants (Figure 4). In contrast, supplying the plants with cattle manure (Figure 5) generally increased the limonene and linalool percentages, but decreased the ocimene and eugenol percentages. Replacing half of the cattle manure rate with bio-fertilization (i.e., using $1 / 2 \mathrm{CM}+$ bio-fertilization) increased the $\beta$-pinene and limonene percentages, but decreased percentages of all other main components, compared to the control. The data presented in Table 8, also show that, in most cases, oil from leaves of control (Figure 4) plants had higher caryophyllene and $\beta$-ionone percentages, compared to those obtained from plants receiving the different fertilization treatments. Also, combinations of $\mathrm{N}$ and bio-fertilization (i.e., $1 / 2 \mathrm{~N}_{1}+$ bio-fertilization, or $\mathrm{N}_{1}+$ bio-fertilization) decreased the ocimene percentage, compared to the control. On the other hand, the limonene, eugenol and $\beta$-ionone percentages were increased by fertilization using $1 / 2 \mathrm{~N}_{1}+$ bio-fertilization, while the $\beta$-pinene and linalool percentages were increased by fertilization using $\mathrm{N}_{1}+$ bio-fertilization.

Among the different treatments, fertilization with $\mathrm{N}_{1}$ appeared to have the best effect on the composition of oil in leaves of Tagetes erecta. Although this treatment gave lower limonene, linalool and $\beta$-ionone percentages than those of the control, yet it gave the highest percentages of ocimene, caryophyllene and eugenol. On the other hand, fertilization with $1 / 2 \mathrm{~N} 1+$ bio-fertilization gave the highest $\beta$-ionone percentage, while using $\mathrm{N}_{1}+$ bio-fertilization gave the highest $\beta$-pinene and linalool percentages, and using $1 / 2 \mathrm{CM}+$ bio-fertilization gave the highest limonene percentage.

Conclusively, From the above results, it is clear that the different fertilization treatments had a generally favourable effect on the growth, flowering, chemical composition and oil production in Tagetes erecta plants. Among the different treatments, using cattle manure (CM) gave the highest values for most of the vegetative growth characteristics (plant height, number of branches, as well as fresh and dry weights of leaves, stems and roots). Also, this treatment gave a high flower production (in terms number of flowers /plant, 
fresh and dry weight of flowers), and a high oil yield (especially from the leaves). In most cases, combining $\mathrm{CM}$ with bio-fertilization caused a slight reduction in plant growth and productivity (compared to using $\mathrm{CM}$ alone), but was still better than using chemical $\mathrm{N}$ fertilization (with or without biofertilization).

\section{REFERENCES}

Abdou, M.A. and A.A. El-Sayed (2002): Effect of planting date and biofertlization treatments on growth and yield characters of Carum carvi $\mathrm{L}$. Proc. $2^{\text {nd }}$ Hort. Sci. Conf., 10-12 Sept., Kafr El-Sheikh, Tanta Univ., Egypt.

Anuradha, K.; K. Pampapathy and N. Narayana (1988). Effect of $\mathrm{N}$ and $\mathrm{P}_{2} \mathrm{O}_{5}$ on the nutrient composition and uptake by marigold (Tagetes erecta L.). South Indian Horticulture, 36(4): 209-211. (C.f. Hort. Abst., 60: 7443).

A.O.A.C. (2000). Association of Official Analytical Chemists. $14^{\text {th }}$ ed., Washington, DC,( Official Methods of Analysis) 822-823. Determination of carotenes and xanthophyll in dried plant materials and mixed feeds.

Arulmozhiyan, R. and C.M. Pappaiah (1989). Studies on the effect of nitrogen, phosphorus and ascorbic acid on the growth and yield of marigold (Tagetes erecta L.) cv. MDU 1. South Indian Horticulture, 37(3): 169-172. (C.f. Hort. Abst., 61: 2956).

Brickell, C. (1996). The Royal Horticultural Society A-Z Encyclopedia of Garden Plants. Dorling Kindersley, Ltd., London. 996-998.

British Pharmacopoeia (1963). Determination of volatile oil in drugs. The Pharmaceutical Press, London.

Bunzen, J.; N. Guichard; J. Labbe; P. Prevot; J. Sperpinet and J. Trenchant (1969). Practical Manual of Gas Chromatography. J. Trenchant Ed., ElSeivier Publ. Co., Amsterdam, London.

Chandrikapure, K.R.; K.T. Sadawrte; D.M. Panchbhai and B.D. Shelke (1999). Effect of bioinoculants and graded doses of nitrogen on growth and flower yield of marigold (Tagetes erecta L.). Orissa Journal of Horticulture, 27(2): 31-34. (C.f. Hort. Abst., 69: 3376).

Chapman, H.D. and P.F. Pratt (1961): Methods of Soil, Plants and Water Analysis. Univ. of California, Division of Agricultural Sciences.

Dubois, M.; F. Smith; K.A. Gilles; J.K. Hamilton and P.A. Rebers (1956). Colorimetric method for determination of sugars and related substances. Annal. Chem., 28 (3): 350-356.

Gouda, H.A.H. (2002): Physiological and biochemical studies on Tagetes erecta, L. and Amaranthus tricolor, L. plants as source of natural pigments. Ph.D. Thesis, Fac. Agric., Cairo Univ., Egypt.

Gupta, N.S.; K.T. Sadavarte; V.K. Mahorkar; B.J. Jadhao and S.V. Dorak (1999). Effect of graded levels of nitrogen and bioinoculants on growth and yield of marigold (Tagetes erecta). Journal of Soils and Crops, 9(1): 80-83. 
Hafez, Y.A.M. (2003): Effect of sow spacings, nitrogenous and biofertilization treatments on growth, yield and chemical composition of Borago officinalis L. Ph.D. Thesis, Fac. Agric., Fayoum, Cairo Univ., Egypt.

Hegazi, N.A.; M.A. Hamza; A. Othman; S. Ali; M.Z. Sedik and M. Fayez (1998). Modified combined carbon $\mathrm{N}$-deficient medium for isolation, enumeration and biomass production of diazotrophs. In Malik Kauser A., Mirza M. Sajjad, Ladha J.K., eds. Nitrogen Fixation with Non-Legumes. Kluwer Academic Publishers, Dordrecht, 247-253.

Jackson, M.L. (1967): Soil Chemical Analysis. Prentice-Hall of India, 144-197.

Jacoub, R.W. (1999): Effect of some organic and non-organic fertilizers on growth, oil yield and chemical composition of Ocimum basilicum L. and Thymus vulgaris L. plants. Ph.D. Thesis, Fac. Agric., Cairo Univ., Egypt.

Marschner, H. (1999): Mineral Nutrition of Higher Plants. Academic Press, London.

Mohamed, M.A. (2003): Taxonomical and physiological studies on periwinkle plants. Ph.D. Thesis, Fac. Agric., Cairo Univ., Egypt.

Piper, C.S. (1947): Soil and Plant Analysis. Univ. of Adelaide, Adelaide, Australia, 258-275.

Pregl, F. (1945): Quantitative Organic Micro-Analysis. $4^{\text {th }}$ Ed., J. and A. Churchill, Ltd., London, 78-85.

Ram, P.; B. Kumar; A. Singh; M. Yaseen and S.K. Kothari (1999). Response of marigold (Tagetes minuta) to irrigation and nitrogen fertilization under Himalayan foot hills of Tarai region of Uttar Pradesh. J. Med. Arom. Plant Sci., 21(2): 361-366.

Rao, E.V.S.P.; K.V. Syamasundar; C.T. Gopinath and S. Ramesh (1999). Agronomical and chemical studies on Tagetes minuta grown in a red soil of a semiarid region in India. Journal of Essential Oil Research, 11(2): 259261.

Sakr, W.R.A. (2005): Effect of organic and bio-fertilization on growth and active constituents production of senna plants. Ph.D. Thesis, Fac. Agric., Cairo Univ., Egypt.

Saric, M; R. Kastrori; R. Curic; T. Cupina and L. geric (1967): Chlorophyll determination. Univ. et M. Novon Sadu. Praktikum Iz Piziologiz Bilyaka Beograd Haucna Ajiga, 215.

Steel, R.C.D. and T.H. Torrie (1980): Principles and Procedures of Statistics. McGraw-Hill, New York, 450.

Yadav, P.K. and S. Singh (1997). Effect of N and FYM on growth and yield of African marigold (Tagetes erecta L.). Environment and Ecology, 15(4): 849- 851. (C.f. Hort. Abst., 67: 5177).

Yadav, P.K.; S. Singh and S.S. Dahiya (1999). Effect of N and FYM on chlorophyll and nutrient content in leaf of African marigold (Tagetes erecta L.) at flower bud initiation stage. Environment and Ecology, 17(1): 188190. 


\title{
إستجابة التباتات الحولية الصيفية المزهرة لمعاملات التسميد الكيماوى و

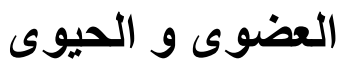 \\ ثانيا - نباتات القطيفة (Tagetes erecta L.)
}

\author{
عفـت إسماعيل المعداوى \\ قسم بساتين الزينة، كلية الزئراعلاعة، جامعة القاهرة- ج.م.ع.
}

أجريت هذه التجربة في حقل تجارب قسم بساتين الزينة بكلية الزراعة، جامعة القاهرة، الجيزة، خلال

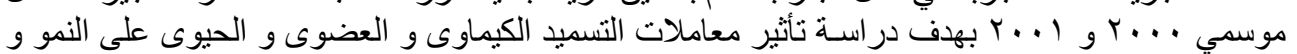
التركيب الكيماوى لنبات القطيفة (Tagetes erecta L.

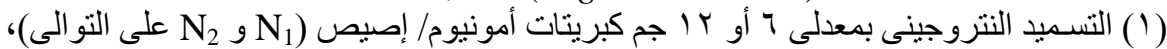

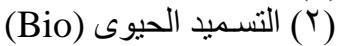

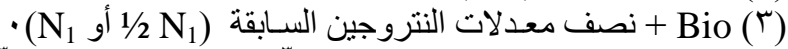

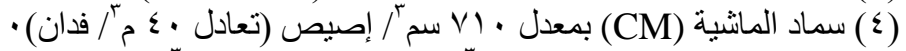

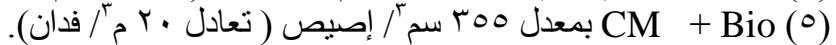

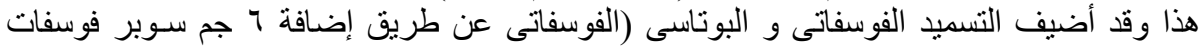

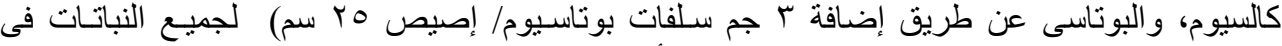

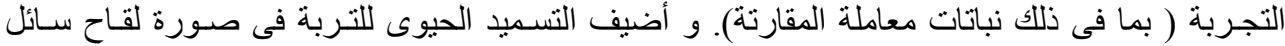

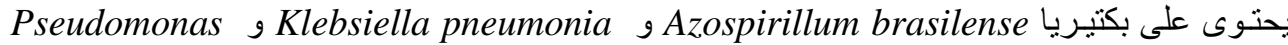

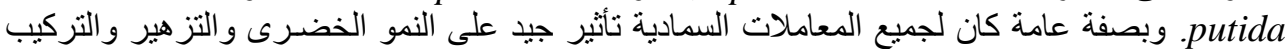

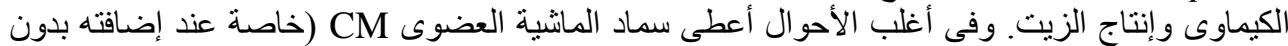

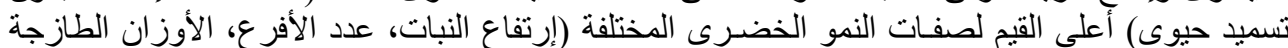
و الجافة للأور اق و السيقان و الجذور ).

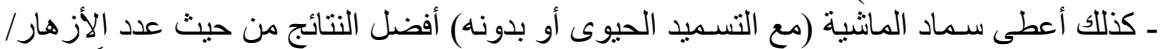

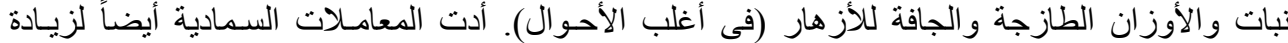

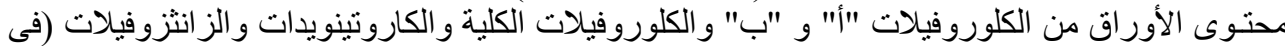

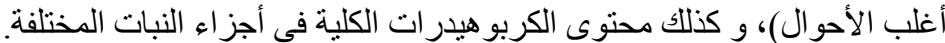

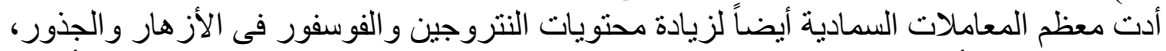

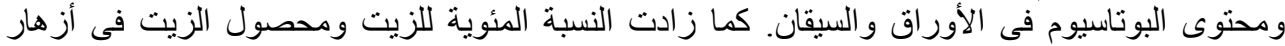

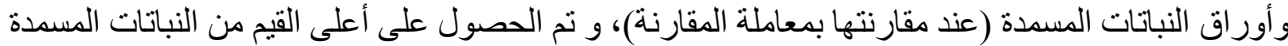

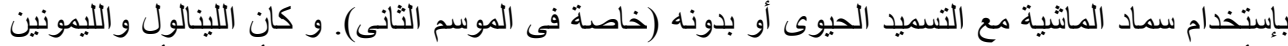

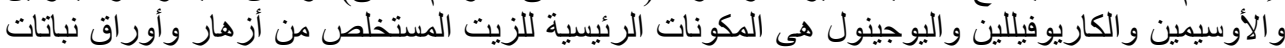

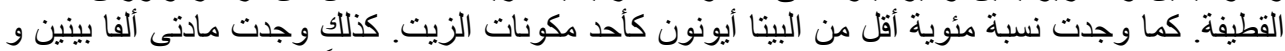

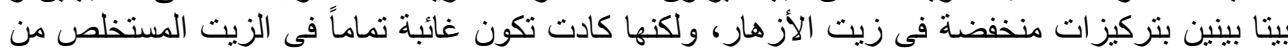

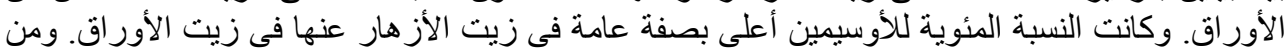

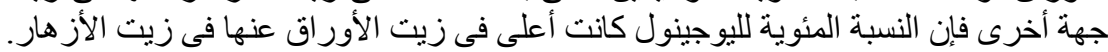

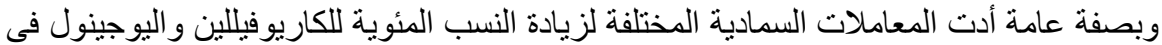

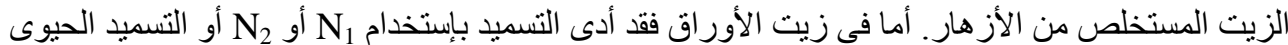

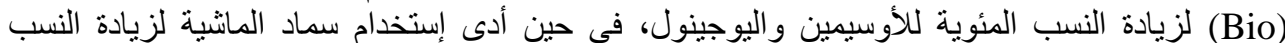

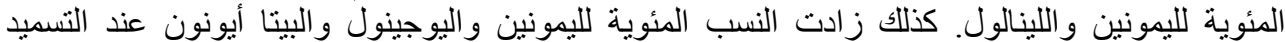

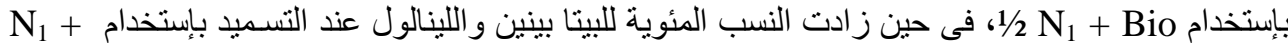
Bio أعلى النسب المئوية للأوسيمين و الكاريو فيللين و اليو جينول في زيت لإيت الأوراق.

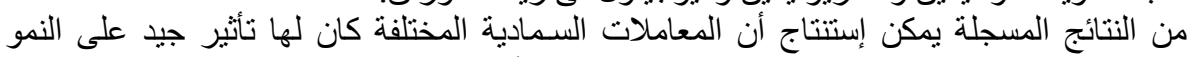
و التز هير و التركيب الكيماوى و إنتاج الزيت فى نباتات القطيفة، وأن التسميد العضوى بإستخدام سماد المانشية أعطى أَفضل النتائج. 